\title{
Netpolitik: A New Political Transformer for Indonesia?
}

\author{
Bustanul Arifin \\ Department of International Relations Study Program \\ President University, Cikarang, Indonesia \\ Bustanul_arifin@president.ac.id \\ Amirah Ulfah \\ Department of International Relations Study Program \\ President University, Cikarang, Indonesia
}

\begin{abstract}
Abstrak
Perkembangan Teknologi Informasi dan Komunikasi (TIK) telah membawa banyak perubahan mendasar dalam praktik politik. Salah satu aspek penting dari TIK adalah internet. Internet ini memainkan peran penting dalam pengembangan era informasi. Oleh karena itu, dunia informasi digital berkontribusi pada cara di mana kita secara efektif dan efisien membuat dan mengkonsumsi sebuah informasi. Dalam penelitian ini, kami focus untuk melihat peran teknologi yang mendorong praktik net politik oleh public dan actor politik di Indonesia. Netpolitik sendiri adalah kombinasi antara internet dan politik. Kemudian, kami menganalisa bagaimana net politik mempengaruhi dan mengubah situasi politik di Indonesia selama beberapa waktu terakhir. Kemudian, kami memasukkan beberapa aspek untuk melihat efek yang didorong oleh netpolitik. Akhirnya, kami menyimpulkan penelitian dengan temuan yang menyatakan bahwa netpolitik telah melakukan transformasi politik di Indonesia dan menjadil okomotif utama dalam menentukan perilaku actor politik dan juga publik.
\end{abstract}

Kata kunci: Internet, Netpolitik, Publik, Aktor Politik, TIK, Era Digital, Transformasi, dan Indonesia

\begin{abstract}
The development of Information and Communication Technologies (ICTs) has brought many fundamental changes in the political practices. One of the main essential aspects of ICTs is internet. This internet plays an important role in developing the information age. Therefore, the information age contributes to the way in which we effectively and efficiently create and consume the information. In this research, we focus to see the role of technology that drives to the practice of netpolitik by both the public and political actors in Indonesia. Netpolitik itself is the combination between internet and politic. Then, we analyze how netpolitik is influencing and changing the political situation in Indonesia during the recent time. Then, we put several aspects in order to see the effects driven by the netpolitik. Finally, we conclude the research by a finding stating that the netpolitik has done a political transformation in Indonesia and it becomes a core engine in determining the behaviour of political actor and audiences.
\end{abstract}

Keywords: Internet, Netpolitik, Public, Political Actors, ICTs, Digital Era, Transformation, and Indonesia 


\section{Introduction}

Early of this 2018, Indonesian government through the Ministry of Communications and Information Technology has announced that the total internet users in Indonesia during 2017 had reached 143.26 million people (Kemkominfo, 2018). This huge number has brought certain changes to the behavi0r of Indonesian people, where Indonesia has now become a very dynamic country for political development. Internet plays a very significant role in every election in Indonesia and also in every political move. It can be seen either in public reaction by using internet or in politician or policy maker action by using internet also. This condition in Indonesia has created a new phenomenon where political information flow is depending on the communication instrument in a significant level. Due to that reason, internet is then becoming really crucial when it will be connected to almost all communication instruments.

It becomes a very common thing to realize for global society nowadays that the widely use of internet is a development part of Information, Communication and Technologies (ICTs). Then, this emerging information age has been characterized by the transparency and volatility in the political practice or social interaction (Kalathil, 2013). Globalization has become a strong engine for a fast growth of the ICTs. Globalization supported by the industrial revolution in Europe and America during early $20^{\text {th }}$ century had produced multiple innovation to boost material and social benefits for people (Ates, 2008). The intention continues to our recent time where competition in technology becomes very serious globally. Today, many companies, institutions, researchers and governments have driven innovation in various sectors including science technology. Those actors are now competing every second in order to create a new product in technology. Their focus cope all aspects of human activities, starting from business interest, social interest to political interest. People are driven to be dependent on the technology use and cannot separate their life from the function of technology to support their life move.

In Indonesia itself, digital technology is holding an important position both for public society and government. One of the most important digital technologies is the emerging of online news media. People are consuming online news media in a big amount in Indonesia starting from artist issues to political situation. Media business entity also puts a serious concern for netizens as the important market for business benefit because characteristically the millennial society prefers to deal with digital product rather than the printed work based on their reason regarding easy access and more simple. Not only an adult, but also a senior high school student or even elementary student in Indonesia has been provided a hand phone by their parents. The reason for that is to be able to monitor their children and make communication easier among them, according to the parents. This character has now driven the people in Indonesia to be really familiar with the digital technology and product. Consequently, products produced by the digital technologies that use internet will be a daily consuming thing in Indonesia and also it becomes the main tool to distribute the information about everything in the country. 
In the context of political situation, everything is interrelated among stakeholders today. For instance, we cannot deny the role of Television, Online News Media, Radio and even Social Media in taking part to involve in the political related mater by providing a space for nonstate actors or mostly the public society to give reaction or provide a new idea to the government. Then, those digital media become an interaction instrument between the policy maker or government and the public or non-state actors. This situation is becoming a very common thing happening in Indonesia recently. The Indonesian government under Jokowi has put digital technology as a crucial media to deliver their program and interest (Detik, 2017). For instance, President Jokowi has used most of his appearance on TV or online media to announce his work progress and what he is doing with his cabinet. Even the minister of Agriculture, Amran Sulaiman this early 2018 announced a new product from his ministry named "Toko Tani" (Tempo, 2017). This is an online platform to trade the products of Indonesian farmers. Furthermore, we can see how Indonesian public gives reaction regarding a corruption case or new regulation product through the social media. It clearly can be seen in Setya Novanto issue, a former chairman of Indonesian parliament, or in the case of AntiCorruption Commission (Komisi Pemberantasan Korupsi/KPK) where the parliament announced to revise the law about the KPK, then the Indonesian public reacted massively on the social media and even academia or other non-state actors use TV to provide responses. Another common example in Indonesia is the use of online or digital tools for the political election interest where candidates and supporters will use internet to gain voters and even to attack the opponent entity like group of buzzers.

The coming of internet to the people interaction nowadays has created a new term called as "Netpolitik" (Bollier, 2003). Netpolitik will refer to the combination between internet and politics. Netpolitik is strongly associated with the practice of politic by using internet. In Indonesia, the political practice is significantly dominated by the use of Internet by both politicians and public. For example, social media is one the most important instruments to react or express towards any political move happening in Indonesia. The case of Ahok during Jakarta governor election has proven the significant role of internet by both public and politician. At this point, the netpolitik comes to give a transformation for the political practice in Indonesia regarding characteristic, strategy and style of politics.

\section{What is Netpolitik?}

Internet has significantly reduced the cost that we need to transmit the information to another party. Starting from individual, multinational corporation, NGO to government, internet becomes the first choice to deliver the information. There are two kinds of cost in this context, firstly is financial cost and secondly is time cost. Both time and money will be the concern when the actor uses the internet, although in some certain cases, actor uses internet because of target of audiences and the impact to audiences.

The netpolitik that arises after the combination between the internet and politic brings a new phenomenon to the society. People can now see this netpolitik is a new type of diplomacy that can be practiced by any actor in order to persuade their interest. Netpolitik is a new style of diplomacy that seeks to exploit the powerful capabilities of the Internet to shape politics, 
culture, values, and personal identity (Bollier, 2013). This has driven to a new form of power that can be used by individuals, corporate, NGOs, and even governments. This will be a form of soft power in the political practice or even in the international diplomacy. "Power in the global information society depends less on territory, military power, and natural resources. Rather, information, technology, and institutional flexibility have gained importance in national politics or international relations. The power of knowledge, beliefs, and ideas are the main tools of political actors in the efforts to achieve their goals" (Bollier, 2013).

In the bigger scope of a nation, internet has played a key role in shifting the national interest of a country, where the development of ICTs drive the country to focus more on economic competitiveness, cyber security, cultural influence and national or international image branding. Furthermore, the ultimate consequence from this internet is to shorten the time. At the end, government officials and public will compete in the form of time. For any case happening inside of a country, it will drive the public to give pressure to the government to provide respond as soon as possible. Where the government should provide information and explanation the public regarding any issue known by the public. In this situation, it will require the government to have two things. Firstly, government should be able to obtain a fast information regarding any issue. Secondly, when they have information then they should have skill to process, calculate and analyze the information as fast as possible.

Jamie F. Metzl in the Geogetown Journal of International Affairs has mentioned strongly regarding the effects caused by the network towards the society structure.

"Networks distribute influence and power across traditional boundaries, allowing powerful interest groups to form and re-form rapidly. The network is flexible and agile, constantly able to reconfigure itself to address new challenges. It allows ideas to compete and confers a competitive advantage on those most able to share, trade, and receive the most relevant information. Networks lower the cost of collective action, making large and disparate groups better able to organize and influence events than ever before" (Metzl, 2001).

It shows the power characteristic brought by the internet to the actor as well as to the audience. At this point, internet will have a significant power to transform the behavior of the actor and audience circumstances in the political environment.

Unfortunately, the practice of this netpolitik will bring a dilemma for all of us. The open source information has fastened the flow of information and it also brings a more diversification of the information to be consumed by the people. Internet will not be able to differentiate the background, culture, education and religion, of the receivers. Internet will use single treatment to almost all types of object or receiver. Finally, this will mostly bring to a multiple subjectivity on any issue (Bollier, 2013). One issue will possibly be interpreted in some meaning based on the actor background. Then, in the very diverse society like in Indonesia, people will mostly often see a different interpretation and perception from each 
individual or actor toward a single information, where this can be a fragile thing in a society when it deals with a sensitive issue.

\section{Public and A New Space}

As everyone might realize, the broadly use of the internet has augmented the intensity of information and communication flow. Individual from one domicile of the world is now able to interact with community from other part of this global civilizations. Publics are now easily communicating one another from separated places as well as having a two ways communication with the government which in the past time seems to have no access at all. If previously communication and the flow of information between the government and the publics is using a top-down system, nowadays the situation has altered due to the adjustment of current massive development of ICTs. Information is no longer from the government to the public only or one-way communication but has transformed into two-ways communication where the public's voice can also be heard by the government.

David Bollier in the journal of Aspen Institute stated:

"The Internet has greatly lowered the costs of transmitting information, enabling people to bypass traditional intermediaries whose power revolved around the control of information: national governments, the diplomatic corps, transnational corporations, and news organizations, among others. As a result, nongovernmental organizations (NGOs), academic experts, diasporic ethnic communities, and individuals are using the Internet to create their own global platforms and political influence" (Bollier, 2013).

The development of ICT especially in the establishment of social media gives a new platform for publics to engage in political agenda. More significantly, its characteristic about low in cost and high in time efficiency is viewed to be more interesting. This new platform can be considered as a new public space to express their feeling, opinion, complement, comment and others. If traditionally, public space is a place which was built so publics can meet or gather and have a discussion. In this digital age, we familiarized with a new type of public space where people do not have to gather physically rather virtually but the discussion can go on.

Number of social network users in Indonesia from 2015 to 2022 (in millions)

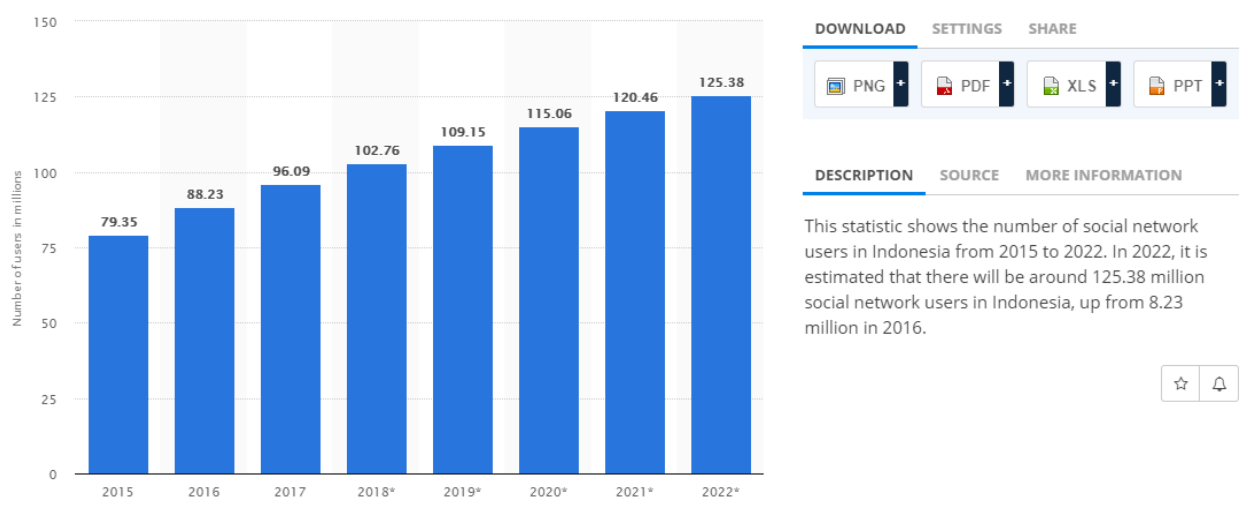

(Statista, 2018) 
Recent fact shows how social media is frequently being used by the society. Even by the years past, number of social media platform was also increasing. If we take a look at Indonesia users of social media, it shows an upsurge number of users for every year and predicted will keep increasing for the next four years. Social media has been a very common new public space in this digital age, publics now can enthusiastically engage and show their concern in every field of information. Not only from their individuals account but also join in a community account to deliver their opinion and interest.

As what we can grasp on what happened in 2017, when the case of Ahok blasphemy toward Islam and the general election for Jakarta governor. Publics were expressing their opinion through social media. They spread information and they open space for discussion and even invite participants across the region. This case however shows another point of view regarding the new platform for public's voice in this digital age. We have to understand that sometimes, this easier access of communication and information also gives a negative consequence. Just like a double-edge sword, in one side it eases the discussion among publics and opens access between public and the government. However, in another side, this condition also leads to many miss-interpretation, bias information and other communication frauds.

Another example of the clutter situation created by free flow of information and the development of ICT is that how society now hold the power to also create a conflict. They can build a wide networking with less-cost equipment and create a propaganda that lead to conflict. It just invites another dilemma in how to respond to this digital age. If previously information can only be received from media which has filtered the information, it seems there was less propaganda compare to what happens today. This free access in open space just gives the opportunity for publics to create a propaganda or blindly accept the propaganda it-self.

In conclusion to this part, we can bravely state that, this digital age has given a very promising public space to engage in the political agenda. Thanks for this development which also leads to two-ways communication between the government and public that is more efficient than before. Unfortunately, we can never forget another side of something, where this free public access also gives possibility to another issue on communication and power control.

\section{Bureaucracies and Political Transformation}

The rise of internet usage is not only giving and providing a new tool for public engagement yet also creates a new way for government in conducting its governmental activity or political agenda. Nicholas Wetscot argues that the internet has three fundamental impacts on politics:

1. It enlarges the number of voice and interest in political agenda especially in decision making process which complicates the system and reduce the power of state

2. It accelerates and eases the dissemination of information. 
3. It improves the traditional diplomatic system to be more effective and efficient which applies to national and international matters(Westcott, 2008)

Therefore, the internet can contribute to the weakening of state power and control by enabling communities to join and act across national boundaries. The new space that publics have right now can be considered as part of control or power that previously owned by the government. The changing situation requires the government to adapt for the current phenomenon of the world system. When the world now has a much tranquil way to conduct its program and communicate with the society, the national government has to catch up the development and applies it to its national matters.

If the state remains staying in its conventional way without trying to adjust the current alteration, then they have to be ready with the competition that becomes more intense in this era. Seeing the positive point from this internet age, there shall not be any hesitation for the government to adjust the system. The state can use the internet to ease the bureaucracy. Right now, we can find any official website from any governmental institution. Publics can find any information in the website and even can do the electronic system of registration and else.

Therefore, the rising levels of internet usage by governments, the private sector and society in general transform to a new era for public administration, (Dunleavy \& Margetts, 2000). Indonesia takes a fast step to adjust to this dynamic world, especially in the changing of some governmental system and its bureaucracy. For example, in terms of economy, Indonesia realizes the importance of internet for the development. Regarding this, Indonesia now has a policy to create a smart country that is characterized by the ability to adopt the technology in this digital age. Indonesia has a big plan to be the biggest digital economy in Southeast Asia. By doing so, Indonesia is giving its best effort to transform the country digitally. In 2017, Indonesia initiates the national program to get 2 million small and medium enterprises online (e-commerce) as well as the development of 1000 start ups in 2020 (Netapp Community, 2016).

Still related to economic growth, The President of Indonesia Joko Widodo created a Presidential Regulation on the Acceleration of the Implementation of Business. It aims to improve the standard of efficient, easy and integrated business licensing services. This should lead to an acceleration of the business licenses issuing process and provide certainty to investors about the period of time and costs in the licensing process. The new policy also aims to utilize information technology through the application of a single permission system. This new system encompasses a single submission system for investors, which means they (investors) only have to go one place to obtain all required licenses(Investments, 2017).

As it is normally realized that netpolitik creates a political dilemma, it is also strongly applied to the changes of government action in conducting its political agenda. Since the government has to adapt and adopt the technology, significantly the internet, it has contributed to the diffusion of power among other actors. Now the flow of communication seems to be horizontal. With the proliferation of intensive use of social media, government officials no 
longer hold "exclusiveness" or total control over both the content and speed of information that they provide to the public. As people are dazed by the news cycle on national and international affairs, their eagerness to learn more and request for greater accountability to the policy decision-maker through media has dramatically increased. In which the use of social media has created a forum for informal and direct dialogue, where passive and hierarchical schemes of international engagement and interaction have totally extinct.

The crumbling of actors that influences policymaking process is disintegrating the conventional role of the official government of any nation in conducting diplomacy. This condition makes the governments and their policy establishments now seem to have less alternative rather to adapt and adopt this new system. Moreover, in a 21 st century environment, government and public officials need to be quickly adjusted and able distinguish the quality or accuracy of information in the rush of open-source data that flows every second through traditional and social media outlets, and need to understand situations, assess plausible scenarios, and talk and reach-out to key actors (Sarukhan, 2013).

Development will always be related to changes. What to highlight is that we will never be able to stop the changes rather to adjust our condition to the situation. It is also applied to the governmental system of bureaucracy. Technology advancement, significantly in the use of internet has a high contribution in the transformation of the system. Whether it will lead to the positive impact or negative one, the transformation will always be there.

\section{Internet and Nationalism}

This digital age with the number of internet user that keeps increasing brought another significance issue to discuss about. Internet and globalization lead to the degradation of individual identity to belong to what society, instead now we are familiar with the term of global citizenship that every individual in this world are living in one place, in one community under one system.

However, it is getting confuse to determine whether this phenomenon presents a positive impact or its reverse. Being in one citizenship that recognizes a part of global, might be a virtuous one that everyone realizes we belong to one, where a problem for one is a problem for all. Just like how we now realize that environmental damage is not a certain group issue but the issue for everyone. However, we still have to contemplate how this global citizenship is erasing national identity. We get used to categorize and diversify ourselves as global citizen not a particular country citizen.

Meanwhile, if we try to see from another point of view, having internet nowadays could also intensify more the sense of nationalism. When a problem comes up, internet helps to distribute information, to invite participation or could be a reminder for citizen regarding their country's problem. Thus, we actually can see that nationalism might be higher in this digital age through the use of digital tools it-self. Even now we have the term of virtual 
nationalism, which defined as the extensive use of computer-based technologies, typically the Internet, by the group of nationalist people. The use of social media and websites by nationalist communities has transformed the structure and context of nationalism as well as the scholarly discourse on related topics in the digital age. Social media enables publics to express their identity, examination and investigation; those phenomena are considered normal for the human experience (Gündüz\&Erdem, 2017).

We can see when Indonesia has had a clash in terms of cultural heritage with Malaysia, publics are expressing their opinion, showing their sense of belonging to support the country. It might be started with one single call by a nationalist and then widely spreads across the region. Therefore, the discussion on the impact of internet in terms of nationalism is still in need to be pursued further or might be it will end up in this current situation that has two points of view.

\section{Competition and Conflict}

The development of netpolitik at the end has brought us to see several new dynamics in the society or even government structure. The behaviour of the people is dramatically changing in this network era. Internet has shaped certain characteristic and behaviour of the people along with their use of internet, particularly this happens to young people. Finally, the coming of internet into society has successfully brought two significant consequences or effects. They are conflict and competition. Internet contributes to create more gap among the people. It also makes individuals to see that they are different with another group or individual. The coming of internet cannot guarantee to provide a harmonisation among the people, however it can put people in a different situation where conflict and competition will be dominant. The reason of this phenomenon is caused by the background of the people. Every individual, government, corporate, group, institution and country, they all will use internet to promote their own interest, culture, religion, values and norms. Each internet user wants to obtain benefit from the use of internet. At this context, the clash between the internet users is possibly real in our world.

In Indonesia, the conflict and competition is not only at the level of information consumer but also at the level of content provider. Not only society will clash, but the media also show a clash one another sometimes. There are several reasons to cause this thing, among them, media interest and leader or politician influence on the media can play a role here. Media then becomes a very crucial determination for the condition stability. The growing political autonomy of local and regional media, using flexible communication technologies, is as important a trend as the globalization of media in shaping public attitudes," writes Manuel Castells (Castells, 2010).

In Indonesia, the competition in the political domain can be seen significantly in the internet platform. The political actors in Indonesia are using internet intensely and this digital instrument becomes the tool for them to play their political agenda. Internet becomes very complex for the political actors nowadays. Internet will be used to spread the individual influence, to make popularity, to promote their ideas, to attack opponent groups, and even to 
do propaganda. Furthermore, the role of internet will be very significant to change the situation circumstances in the society and to bring certain dynamic to the country. Among the political leaders in Indonesia, we can usually see many negative statements addressing the weakness or the bad things of their opponent groups. The political actors in Indonesia are commonly showing the characteristic of competition to another actor outside of their group. That is the reason of the emergence of political volatility in Indonesia. People are competing to put their interest in the first step, and they are thinking to weaken the other entities.

Internet brings multiple effects to the audiences, where it can also cause competition and conflict on the internet as mentioned by Klaus Grewlich:

"Because of its pluralizing potential, the Internet increases the likelihood that transnational conflicts will arise-but because there is no sovereign international authority to adjudicate and, especially, to enforce, the resolution of Internet-driven conflicts is highly complex. At the same time, the Internet and information technology have the potential to fractionate the public because they allow individuals to customize the information they receive" (DOI, 2001).

In addition, the development of this netpolitik has also brought a certain conflict in both public society and political actors. The uncertainty and incorrect information spreading on the internet has contributed to the conflict among publics or political leaders. Indonesia with a very diverse public background and character will have multiple interpretation on the meaning of the information that they get from the digital platform. The different interpretation among the people, will possibly have potential to bring a conflict among them. Similarly, the different view owned by the political leaders in seeing certain issue, will bring them to blame or attack one another, and at the end will have a certain gap among them and likely a conflict.

\section{Conclusion}

The role of netpolitik in the political circumstances is undeniable in this digital era. It plays a very significant role to shape or influence the political practice in Indonesia. Internet is the engine and core of the netpolitik in every place nowadays. In Indonesia, the political situation is now significantly determined by the interaction between the public and the political actor or officials to official as well. In this interaction, internet is very dominant to take a place. The practice of politic will always bring interaction between public as main audience and political stakeholders. Then, the characteristic of the political practice in Indonesia will be influenced by the netpolitik itself.

The behavior of publics and political actors recently is determined by the degree of internet use. The changes in the digital behavior will now change the political situation and outcomes as well. The netpolitik is now a dependable thing for people in Indonesia. Consequently, the netpolitik has transformed the political practice and situation in Indonesia to a new degree and it is very different to the past years where the use of internet was not as significant as our recent time. The transformation will continue along with the ICTs development and progressivity. 


\section{References}

Bowie, Alisdair (1994). The Dynamic of Business-Government Relations in Industrializing Malaysia.In Andrew MacIntyre (Ed.), Business and Government in Industrialising Asia (p. 167-194). Ithaca: Cornell University Press.

Crouch, Harold (1996). Government and Society in Malaysia. Sydney: Allen \&Unwin.

Global Annual Review (2010).In Political and Economy Centre (PERC). Retrieved April 30, 2011, from PERC database www.asiarisk.com.

Global Competitiveness Index (GCI) (2009-2010) World economic forum-Global competitiveness.Retrieved 2 Mei, 2011, fromwww.weforum.org/issues/globalcompetitiveness.

Global Competitiveness Index (GCI) (2010-2011) World economic forum-Global competitiveness.Retrieved 2 Mei, 2011, from www.weforum.org/issues/globalcompetitiveness.

Gomez, Edmund T \&Jomo K.S (1997).Malaysia's Political Economy: Politics, Patronage and Profits. London: Cambridge University Press.

Hilley, Hilley (2001). Malaysia: Mahathirism, Hegemony, and the New Opposition. London: Zed Books.

Samihah Khalil \&EndiHaryono. "An Examination of Government Bureaucracy in Facilitating Business: Comparing Malaysia and Indonesia”, Proceeding International Conference of Schools and Institutes in Administration (IASIA), Rome Italy, 13-18 June 2011.

Samihah Khalil \&EndiHaryono. "Building Government Competitiveness in Post Financial Crisis: Comparing Views from Malaysia and Indonesia”, Proceeding International Conference on International Studies (ICIS), Kuala Lumpur, 1-3 December 2010.

The 2009 Budget Speech Report (August 29, 2008). A caring government.Dewan Rakyat.Retrieved April 25, 2011, from http://www.treasury.gov.my/pdf/budget/bs09.pdf.

The 2010 Budget Speech Report (October 23, 2009). 1Malaysia, together we prosper. Dewan Rakyat.Retrieved April 26, 2011, from http://www.treasury .gov.my/pdf/ budget/bs10.pdf.

The 2011 Budget Speech Report (October 15, 2010). Transformation towards a developed and high-income nation.Dewan Rakyat.Retrieved April 27, 2011, from http://www. treasury.gov.my/ pdf/ budget/bs11.pdf.

The New Straits Times, April 10, 2009. 
The New Straits Times, April 10, 2009.

The New Straits Times, April 4, 2009.

The New Straits Times, April 6, 2009.

The New Straits Times, June 6, 2009.

The New Straits Times, May 31, 2010.

World Bank Report (2010). On doing business 2011. Retrieved April 28, 2011, from http://www.worldbank.org/ 